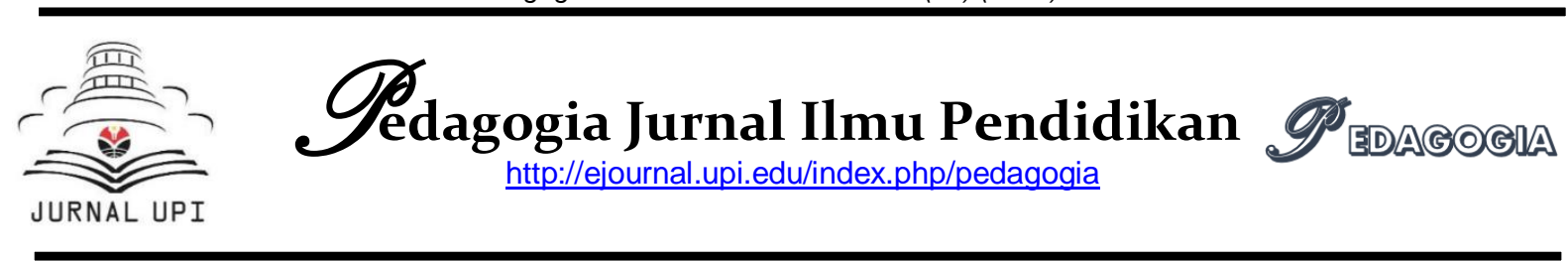

\title{
Efektivitas Media Pembelajaran Lectora Inspire dalam Meningkatkan Hasil Belajar Peserta didik pada Mata Pelajaran Biologi
}

\author{
Ghian Muhammad Rizqi Firmansyah \\ Rusman \\ Kurikulum dan Teknologi Pendidikan \\ Fakultas IImu Pendidikan \\ Universitas Pendidikan Indonesia \\ ghianrizki3151@gmail.com
}

\begin{abstract}
A bstract
This study aims to examine the differences in the increase in learning outcomes between students who use Lectora Inspire learning media compared with students who use media learning presentations on Biology subjects. The general problem formulation is how the effectiveness of Lectora Inspire learning media in improving student learning outcomes on biology subjects. This study uses a quantitative approach with quasi-experimental research methods. The research subjects were class XI students of SMAN 1 Cibeber, consisting of four XI IPA classes totaling 131 students, this study used two classes as samples where the XI IPA 2 class consisted of 33 people (control class) and XI IPA 3 class with 33 people (experimental class). The research instrument was in the form of experimental class and control class with data collection techniques using pre-test and post-test. Based on the results of the research that has been done, it shows that the increase in student learning outcomes using Lectora Inspire learning media is higher and significant compared to students who use presentation learning media by using learning resources in the form of student handbooks. This can be seen by considering the gain between the experimental class and the control class which states that the gain of the experimental class is higher than the gain of the control class in the whole session so that the Lectora Inspire learning media can be said to be effective.
\end{abstract}

Keywords: Learning Media, Lactora Inspire, Biology Subject

\footnotetext{
Abstrak

Penelitian ini bertujuan untuk menguji perbedaan peningkatan hasil belajar antara peserta didik yang menggunakan media pembelajaran Lectora Inspire yang dibandingkan dengan peserta didik yang menggunakan media pembelajaran presentasi pada mata pelajaran Biologi. Rumasan masalah secara umum yaitu bagaimana efektifitas media pembelajaran Lectora Inspire dalam meningkatkan hasil belajar peserta didik pada mata pelajaran biologi. Penelitian ini menggunakan pendekatan kuantitatif dengan metode penelitian kuasi eksperimen. Subjek penelitian adalah peserta didik kelas XI SMAN 1 Cibeber, terdiri dari empat kelas XI IPA berjumlah 131 peserta didik, penelitian ini menggunakan dua kelas sebagai sampel dimana kelas XI IPA 2 yang berjumlah 33 orang (kelas kontrol) dan kelas XI IPA 3 yang berjumlah 33 orang (kelas eksperimen). Instrument penelitian berupa tes kelas eksperimen dan kelas kontrol dengan teknik pengumpul data menggunakan pre-test dan post-test. Berdasarkan hasil penelitian yang telah dilakukan,
}

\begin{tabular}{|c|}
\hline Article Info \\
\hline $\begin{array}{l}\text { Naskah Diterima: } \\
\text { 2019-04-22 }\end{array}$ \\
\hline $\begin{array}{l}\text { Naskah Direvisi: } \\
\text { 2019-04-23 }\end{array}$ \\
\hline $\begin{array}{l}\text { Naskah Disetujui: } \\
\text { 2019-05-28 }\end{array}$ \\
\hline
\end{tabular}


menunjukan bahwa peningkatan hasil belajar peserta didik yang menggunakan media pembelajaran Lectora Inspire lebih tinggi dan signifikan dibanding dengan peserta didik yang menggunakan media pembelajaran presentasi dengan berbanduan sumber belajar berupa buku pegangan peserta didik. Hal tersebut dapat diketahui dengan memperhatikan selisih (gain) antara kelas eksperimen dan kelas kontrol yang menyatakan bahwa gain kelas eksperimen lebih tinggi dari gain kelas kontrol dalam keseluruhan sesi sehingga media pembelajaran Lectora Inspire dapat dikatakan efektif.

Kata Kunci: Media Pembelajaran, Lactora Inspire, Mata Pelajaran Biologi 


\section{A. PENDAHULUAN}

Penggunaan media di dalam proses pembelajaran menjadi alternatif bagi pendidikan yang inovatif. Media pembelajaran dapat mempermudah dalam penyampaian informasi atau pesan pembelajaran kepada peserta didik, selain itu media juga dapat membangkitkan minat belajar peserta didik serta dapat berpengaruh pada hasil belajar peserta didik. Pembelajaran di era teknologi saat ini, banyak memanfaatkan media berbasis teknologi informasi atua bisa disebut Information Cumunication Technology (ICT). "Dalam Bahasa sederhana ICT adalah suatu perangkat teknologi yang memfasilitasi penggunanya dengan berbagai kemudahan dalam mengakses informasi yang dibutuhkan, baik informasi yang disajikan dalam bentuk tulisan, suara, visual, maupun dalam bentuk simbol atau lambang informasi lainnya." (Prawiradilaga, 2013 , hlm. 16).

Pemanfaatan teknologi saat ini sudah membuka banyak peluang di berbagai bidang kehidupan terutama di bidang pendidikan. Hal ini tentu mengisyaratkan kepada pendidik maupun calon pendidik agar mampu menerapkan cara belajar dengan pemanfaatan teknologi. Artinya pendidik dan calon pendidik harus bisa dan paham akan kemajuan teknologi agar dapat menjalankan tugasnya dengan baik sesuai dengan kurikulum yang berlaku serta pembelajaran yang menuju ke arah yang lebih inovatif.

Keberadaan media pembelajaran dalam suatu proses pembelajaran memiliki peranan yang penting dalam meningkatkan efektivitas proses komunikasi dan mempermudah proses penyaimpaian informasi yang disampaikan oleh pendidik kepada peserta didik. Ditegaskan dalam Sukiman (2012, hlm. 44) bahwa "media pembelajaran dapat memperjelas penyajian pesan dan informasi sehingga dapat memperlancar dan meningkatkan proses dan hasil belajar". Oleh karena itu, berdasarkan pernyataan di atas mengingat pentingnya peran serta fungsi media pembelajaran dalam menunjang keberhasilan suatu proses pembelajaran, perlu adanya suatu upaya untuk mengoptimalkan pemanfaatan serta penggunaan media pembelajaran. Khususnya dalam mata pelajaran Biologi pada jenjang Sekolah Menengah Atas.

Hasil pengamatan penulis, ditemukan beberapa gunu di SMAN 1 Cibeber masih menggunakan metode ceramah dalam proses pembelajaran. Para guru jarang sekali menggunakan media pembelajaran khususnya mediia pembelajaran berbasis ICT dan terdapat beberapa guru yang masih belum bisa membuat media pembelajaran interaktiif. Dari beberapa guru yang peneliti amati, hanya beberapa yang menggunakan media pembelajaran berbasis ICT, itu pun pada mata pelajaran tertentu dan hanya menggunakan media presentasi di kelas saja, peserta didik pun mendapatkan pengalaman belajar yang kurang, khususnya pengalaman terkait dengan penggunaan media pembelajaran berbasis teknologi informasi dan komunikasi.

Data yang peneliti dapatkan dari hasil wawancara di SMAN 1 Cibeber, peneliti melihat akan adanya ancaman dari perkembangan teknologi yang dihadapi sekolah, khususnya pada proses pembelajaran, dimana peserta didik menggunakan device atau android mereka saat pembelajaran berlangsung sehingga mengganggu dalam proses pembelajaran. Dari masalah tersebut peneliti melihat peluang untuk memanfaatkan fasilitas belajar di sekolah SMAN 1 Cibeber dengan device berbasis android yang peserta didik miliki untuk menjadikan suatu proses pembelajaran yang menarik dan efektif sehingga tujuan pembelajaran dapat 
tercapai deengan baik. Menyadari akan fasilitas SMAN 1 Cibeber yang memumpuni, akan tetapi kurang dimanfaatkan dengan baik dan di jalankan sesuai prosedur untuk mengefektifkan proses pembelajaran, peneliti menjadikan SMAN 1 Cibeber sebagai objek penelitian untuk meneliti efektivitas dari media pembelajaran Lectora Inspire dalam meningkatkan kompetensi pengetahuan peserta didik pada ranah kognitif.

Tabel 1.1

Nilai Rata-Rata Ujian Tengah Semester Mata Pelajaran Biologi Semester Ganjil Tahun Ajaran 2018/2019

\begin{tabular}{lcc}
\hline No & Kelas & $\begin{array}{c}\text { Nilai rata-rata Ujian Tengah Semester Mata Pelajaran Biologi } \\
\text { Semester Ganjil Tahun Ajaran 2018/2019 }\end{array}$ \\
\hline 1 & XI IPA 1 & 65.4 \\
\hline 2 & XI IPA 2 & 60.57 \\
\hline 3 & XI IPA 3 & 65.20 \\
\hline 4 & XI IPA 4 & 66.01 \\
\hline
\end{tabular}

Dalam tabel di atas terlihat bahwa nilai rata-rata peserta didik kelas XI IPA pada mata pelajaran Biologi masih belum mencapai nilai kriteria ketuntasan minimal (KKM) yaitu nilai KKM untuk mata pelajaran Biologi pada kelas XI IPA adalah 70. Oleh karena sebab itu maka sangat diperlukan adanya suatu upaya untuk meningkatkan kualitas pembelajaran yang selama ini dilakukan agar hasil belajar yang diperoleh peserta didik khususnya pada mata pelajaran Biologi dapat meningkat dan dapat mencapai nilai kriteria ketuntasan minimum yang ditetapkan.

Oleh karena itu, atas dasar berbagai permasalahan yang dipaparkan di atas, maka peneliti akan mencoba memberikan suatu bentuk pemecahan masalah yakni, peneliti akan mencoba membuat sebuah media pembelajaran berbasis Mobile Learning yang dapat dibuat dengan mudah dalam aplikasi Lectora Inspire .

Penggunaan media pembelajaran Lectora Inspire dalam materi pelajaran, didesain semenarik mungkin, di dalam media pembelajaran Lectora Inspire dapat menampilkan video, serta gambar gambar animasi yang berhubungan dengan materi pelajaran kita inginkan yang berhubungan dengan materi pelajaran agar peserta didik lebih memperhatikan apa yang disampaikan oleh guru. Proses pembelajaran akan lebih menyenangkan dan bermakna tentunya memberikan pengalaman belajar yang berbeda bagi peserta didik, sehingga berpengaruh pada peningkatan prestasi belajar peserta didik. (Salikhah, 2017, hlm 11 ).

Berdasarkan dari pemaparan di atas, penulis akan mencoba mengkaji terkait efektivitas penggunaan media pembelajaran Lectora Inspire pada mata pelajaran biologi dalam upaya meningkatkan kompetensi belajar peserta didik pada ranah kognitif yang dibatasi hanya pada tiga aspek yaitu, aspek memahami (C2), aspek menerapkan (C3), dan aspek menganalisis (C4) menggunakan media pembelajaran Lectora Inspire . 


\section{B. TINJAUAN PUSTAKA}

\section{Media Pembelajaran}

Media ialah suatu alat yang digunakan untuk mempermudah pekerjaan manusia. Perannya dalam dunia pendidikan, pengajar sering kali menggunakan media untuk mengajar yang biasa kita sebut dengan media pembelajaran. Rusman (2012, hlm. 160) mengemukakan bahwa media pembelajaran merupakan suatu teknologi pembawa pesan yang dapat digunakan untuk keperluan pembelajaran dan merupakan sarana fisik menyampaikan materi pelajaran.

Media itu sendiri berasal dari bahasa latin medius yang secara harfiah berarti tengah, perantara atau pengantar. Dalam kajian bahasa lain yiatu bahasa Arab, media adalah perantara atau pengantar pesan dari pengirim kepada penerima pesan (Arsyad, 2011, hlm. 3). Menurut Gerlach dan Ely yang dikutip oleh Arsyad (2011, hlm. 3), media apabila dipahami secara garis besar adalah manusia, materi dan kejadian yang membangun kondisi yang membuat peserta didik mampu memperoleh pengetahuan, keterampilan atau sikap. Dalam pengertian ini, guru, buku teks, dan lingkungan sekolah merupakan media. Sedangkan menurut Criticos yang dikutip oleh Daryanto (2011, hlm. 4) media merupakan salah satu komponen komunikasi, yaituisebagai pembawa pesan atau materi dari pengirim atau komunikator kepada penerima atau komunikan.

Mengenai klasifikasi tingkatan suatu media, adalah dari yang paling kongkrit ke yang paling abstrak. Oleh karena itu, media pembelajaran memiliki jenis yang bermacam-macam.

Sejalan dengan pendapat Anitah (2010, hlm, 7) mengklasifikasikan jenis jenis media kedalam empat jenis, "media visual, media audio, media audio visual, dan multimedia." a) Media visual, yakni media yang menggunakan indera penglihatan dalam penggunaannya, karena pesan yang disajikan hanya dalam bentuk gambar saja.

b) Media audio, yakni media yang menggunakan suara atau bunyi dalam proses penyampaian pesan dengan menggunakan indera pendengarannya.

c) Media audio visual, media yang tidak hanya dapat dilihat dan diamati saja, namun sekaligus dapat mendengar sesuatu untuk di visualisasikan

d) Multimedia, merupakan penggunaan berbagai jenis media secara berurutan untuk menyajikan materi pelajaran, namun tidak harus selalu menggunakan alat alat canggih, bisa mengkombinasikan antara media tradisional dengan media komputer.

\section{Mobile Learning}

Mobile Learning adalah suatu pembelajaran yang menggunakan teknologi dalam pembelajarannya yang di mana penggunaan gadget. Istilah mobile Learning mengacu kepada penggunaan perangkat teknologi informasi yang dapat di genggam dan bergerak, seperti gadget, telepon genggam, tablet PC atau laptop. Mobile learning yang merupakan bagian dari e-learning sehingga dapat dikatakan merupakan bagian dalam distance learning yang dapat digambarkan oleh Tamimuddin (2007, hlm. 4), sebagai berikut:

Mobile Learning didefinisikan oleh Clark Quinn (2000 dalam Tamimuddin, 2007, hlm, 3) sebagai "The intersection of mobile computing and e-Learning: accessible resources wherever you are, strong search capabilities, rich interaction, powerful support for effective Learning, and performance-based assessment. 
E-Learning independent of location in time or space."

Merujuk dari definisi tersebut maka, mobile learning adalah model pembelajaran yang menggunakan teknologi informasi dan komunikasi. Pada konsep pembelajaran tersebut mobile learning membawa manfaat ketersediaan materi ajar yang dapat diakses setiap saat dan visualisasi materi yang menarik. Perlu diperhatikan juga, bahwa tidak setiap materi pembelajaran cocok memanfaatkan mobile learning.

\section{Mobile Learning atau m-Learning} sering didefinisikan sebagai e-Learning melalui perangkat komputasi mobile menurut Andy (dalam marfuah 2007, hlm, 6), mendefinisikan mobile Learning yaitu penyampaian bahan pembalajaran elektronik pada alat komputasi mobile agar dapat diakses darimana saja dan kapan saja. Pada umumnya, perangkat mobile berupa telepon genggam digital dan gadget. Namun, secara lebiih umum dapat didefinisikan sebagai perangkat apapun yang berukuran cukup kecil, dapat bekerja sendiri, dapat dibawa setiap waktu dalam kehidupan sehari-hari, dan yang dapat digunakan untuk beberapa bentuk pembelajaran. Perangkat kecil ini dapat dilihat sebagai alat untuk mengakses konten, baik disimpan secara local pada device maupun dapat dijangkau melaluii interkoneksi. Perangkat ini juga dapat menjadi alat untuk berinteraksi dengan orang lain, seperti chatting, baik melalui suara, maupun saling bertukar pesan tertulis, dan dapat pula berisikan konten gambar diiam dan gambar bergerak.

Mobile learning pada dasarnya ada dalam dua versim menurut Darmawan (2012, hlm. 344) yaitu versi offliine dan online, dalam versi offline konten mobile learning dapat diakses dan digunakan tanpa terkoneksi dengan internet, sedangkan dalam versi online diperlukan koneksi dalam interaksi dan isi konten, namun bisa melakukan interakasi antar pengajar dengan pelajar, berupa diskusi dan tanya jawab.

\section{Lectora Inspire}

Lectora Inspire merupakan pembelajaran elektronik (e-learning) alat pengembangan, juga dikenal sebagai perangkat lunak authorim, dikembangkan oleh Trivantis Corporation Australia. Lectora digunakan untuk membuat kursus pelatihan online, penilaian, dan presentasi (Wijaya 2018, hlm, 8). Lectora Inspire merupakan program yang efektif dalam membuat media pembelajaran.

Lectora Inspire disebut juga sebagai software pengembangan belajar elektronik (e-learning) yang relatif mudah diaplikasikan atau diterapkan karena tidak memerlukan pengetahuan dan keterampilan bahasa pemograman yang canggih. Karena Lectora Inspire memiliki antar muka yang populer dengan kita yang telah mengenal maupun menguasai Microsoft Office.

Menurut Suharmoyo (2016) berikut adalah tampilan dan fungsi dari perangkat lunak Lectora Inspire 17.

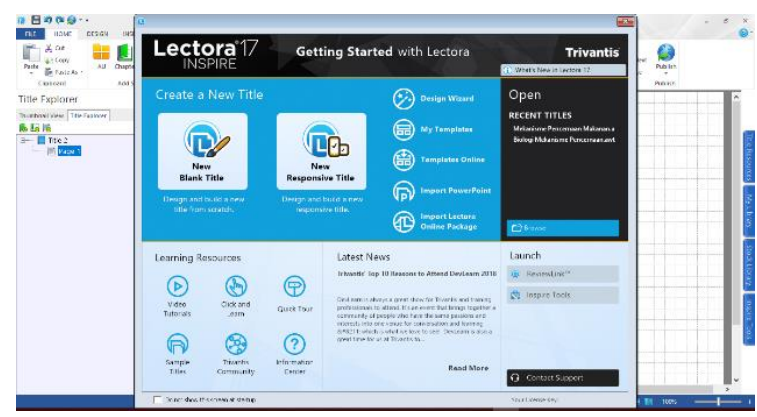

Menurut Salikhah ( 2017 hlm 13) keunggulan dari Lectora Inspire ialah sangat mudah digunakan dalam pembuatan media pembelajaran dan padat membuat materi uji atau evaluasi. Para guru yang tidak terlalu mahir mengoprasikan komputer, akan dengan mudah menggunakan aplikasi ini. Dalam lectora inspire terdapat banyak gambar, animasi, karakter animasi yang dapat 
kita gunakan secara langsung. (Mas'ud, 2012, hlm 3).

Dengan menggunakan program aplikasi lectora inspire kita guru dapat menggunakannya dalam menyiapkan bahan ajar bagi peserta didik.

Menurut Salikhah ( 2017 hlm 13) terdapat tujuh manfaat dari aplikasi Lectora Inspire dalam pengembangan media pembelajaran interaktif, di antaranya adalah sebagai berikut :

a. Guru dapat membuat dan menyajikan materi ajar dengan tanpa harus melakukan programming.

b. Guru dapat melakukan pengujian terhadap materi ajar yang diberikan, dalam berbagai macam bentuk test seperti pilihan ganda, benar/salah, mencocokkan (mathcing), tarik dan tempatkan (drag and drop), isian singkat (fill in the blank), dan hot spot.

c. Guru/peserta didik dapat mengakses materi ajar/uji yang dibutuhkan baik secara offline maupun online.

d. Mampu menggunakan teks, suara, video, animasi dalam suatu kesatuan.

e. Mampu memvisualisasikan materi yang abstrak.

f. Membawa objek yang sangat besar atau berbahaya dalam lingkungan kelas.

g. Menampilkan objek yang tidak bisa dilihat oleh mata telanjang.

\section{METODE PENELITIAN}

Desain penelitian yang digunakan dalam penelitian ini adalah PretestPosttest Nonequivalent Control Group Design yang merupakan salah satu bentuk desain penelitian dalam quasi experiment. Dengan demikian peneliti menggunakan kelas eksperimen dan kelas control sebagai pembanding yang terlebih dahulu masing-masing sampel diberi pretest kemudian untuk kelas eksperimen diberi perlakuan dengan proses belajar mengajar dikelas menggunakan media pembelajaran Lectora Inspire yang telah dibuat oleh peneliti berbasis android dan di akhiri pembelajaran masing-masing sampel diberi posttest. Sementara untuk kelas kontrol akan menggunakan media presentasi yang biasa diterapkan di sekolah dengan berbantuan suber belajar buku pegangan peserta didik.

Populasi pada penelitian ini adalah peserta didik kelas XI di SMAN 1 Cibeber. Peneliti ini menggunakan Cluster Random Sampling dalam menentukan sampel yang digunakan, karena pada penelitian ini menggunakan sampel berdasarkan kelas.

Alasan peneliti memilih teknik cluster random sampling karena sampel yang akan diambil untuk penelitian adalah kelompok peserta didik yang telah terbentuk sebelumnya oleh sekolah dan dibantu oleh guru mata pelajaran Biologi, demikian sampel pada penelitian ini ialah seluruh peserta didik kelas XI IPA 2 SMAN 1 Cibeber yang berjumlah 22 (tiga puluh tiga) orang peserta didik sebagai kelas kontrol dan kelas XI IPA 3 sebagai kelas eksperimen yang berjumlah 33 (tiga puluh tiga) peserta didik.

\section{HASIL DAN PEMBAHASAN}

1. Deskripsi Hasil Penelitian Aspek Memahami (C2) Kelas Eksperimen dan Kelas Kontrol

Rumusan masalah yang pertama adalah "apakah terdapat perbedaan peningkatan hasil belajar peserta didik yang signifikan pada aspek Memahami (C2) antara yang menggunakan media pembelajaran Lectora Inspire dengan yang menggunakan media pembelajaran presentasi dalam mata pelajaran Biologi pada pokok bahasan Mekanisme 
Pencernaan Makanan pada Manusia di SMAN 1 Cibeber?". Adapun tujuan penelitian dari rumusan masalah yang pertama adalah untuk menguji efektivitas penggunaan media Lectora Inspire dalam peningkatan aspek Memahami (C2) peserta didik pada mata pelajaran Biologi.
Setelah dilakukan penelitian diperoleh data pre-test dan post-test pada kelas eskperimen dan kontrol dengan perlakuan pada aspek Memahami (C2). Perbedaan peningkatan hasil belajar peserta didik tersebut dapat dilihat melalui gain pada tabel berikut.

\section{Tabel 1.2}

Rata-Rata Skor Pre-Test dan Post-Test Aspek Memahami (C2) Kelas Eksperimen dan Kelas Kontrol

\begin{tabular}{cccc}
\hline Kelas & Pretest & Posttest & Gain \\
\hline Eksperimen & 3,33 & 4,45 & 1,12 \\
\hline Kontrol & 2,03 & 2,42 & 0,39 \\
\hline
\end{tabular}

Berdasarkan skor rata-rata pre-test dan post-test pada aspek Memahami (C2) untuk kelas eksperimen dan kontrol sesuai tabel 1.2 diperoleh grafik rata-rata sebagai berikut:

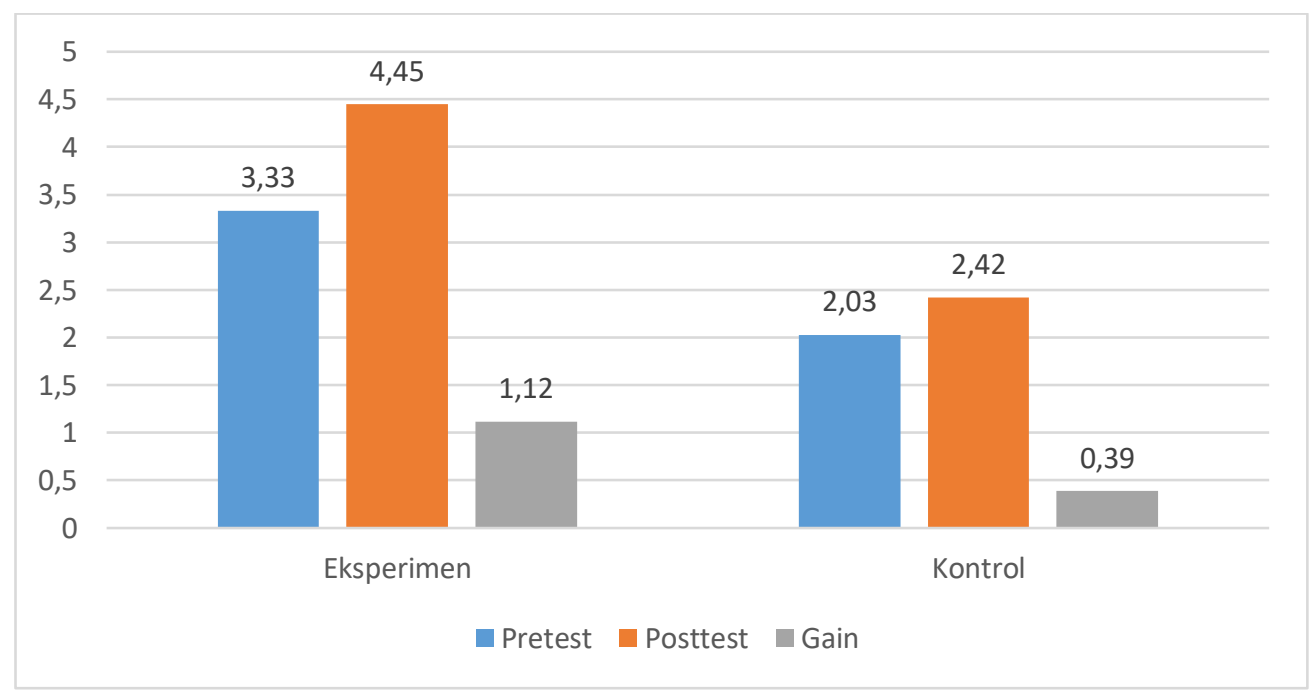

Gambar 1.1

Grafik Rata-rata Skor Awal dan Akhir Aspek Memahami (C2) Keseluruhan

Dari grafik di atas dapat disimpulkan bahwa skor rata-rata post-test dan gain hasil belajar aspek Memahami (C2) kelas eksperimen lebih tinggi dibandingkan dengan skor rata-rata post-test dan gain hasil belajar kelas kontrol.

\section{Deskripsi Hasil Penelitian Aspek Menerapkan (C3) Kelas Eksperimen dan Kelas Kontrol}

Rumusan masalah yang kedua adalah "apakah terdapat perbedaan peningkatan hasil belajar siswa yang signifikan pada aspek Menerapkan (C3) antara yang menggunakan media pembelajaran Lectora Inspire dengan yang menggunakan media pembelajaran 
presentasi dalam mata pelajaran Biologi pada pokok bahasan Mekanisme Pencernaan Makanan pada Manusia di SMAN 1 Cibeber?". Adapun tujuan penelitian dari rumusan masalah yang pertama adalah untuk menguji efektivitas penggunaan media Lectora Inspire dalam peningkatan aspek Menerapkan (C3) siswa pada mata pelajaran Biologi.
Setelah dilakukan penelitian diperoleh data pre-test dan post-test pada kelas eskperimen dan kontrol dengan perlakuan pada aspek Menerapkan (C3). Perbedaan peningkatan hasil belajar siswa tersebut dapat dilihat melalui gain pada tabel berikut.

Tabel 1.3

Rata-Rata Skor Pre-Test dan Post-Test Aspek Menerapkan (C3) Kelas Eksperimen dan Kelas Kontrol

\begin{tabular}{llll}
\hline Kelas & Pretest & Posttest & Gain \\
\hline Eksperimen & 1,76 & 3,73 & 1,97 \\
\hline Kontrol & 1,70 & 2,00 & 0,30 \\
\hline
\end{tabular}

Berdasarkan skor rata-rata pre-test dan post-test pada aspek Menerapkan (C3) untuk kelas eksperimen dan kontrol sesuai tabel 1.3 diperoleh grafik rata-rata sebagai berikut:

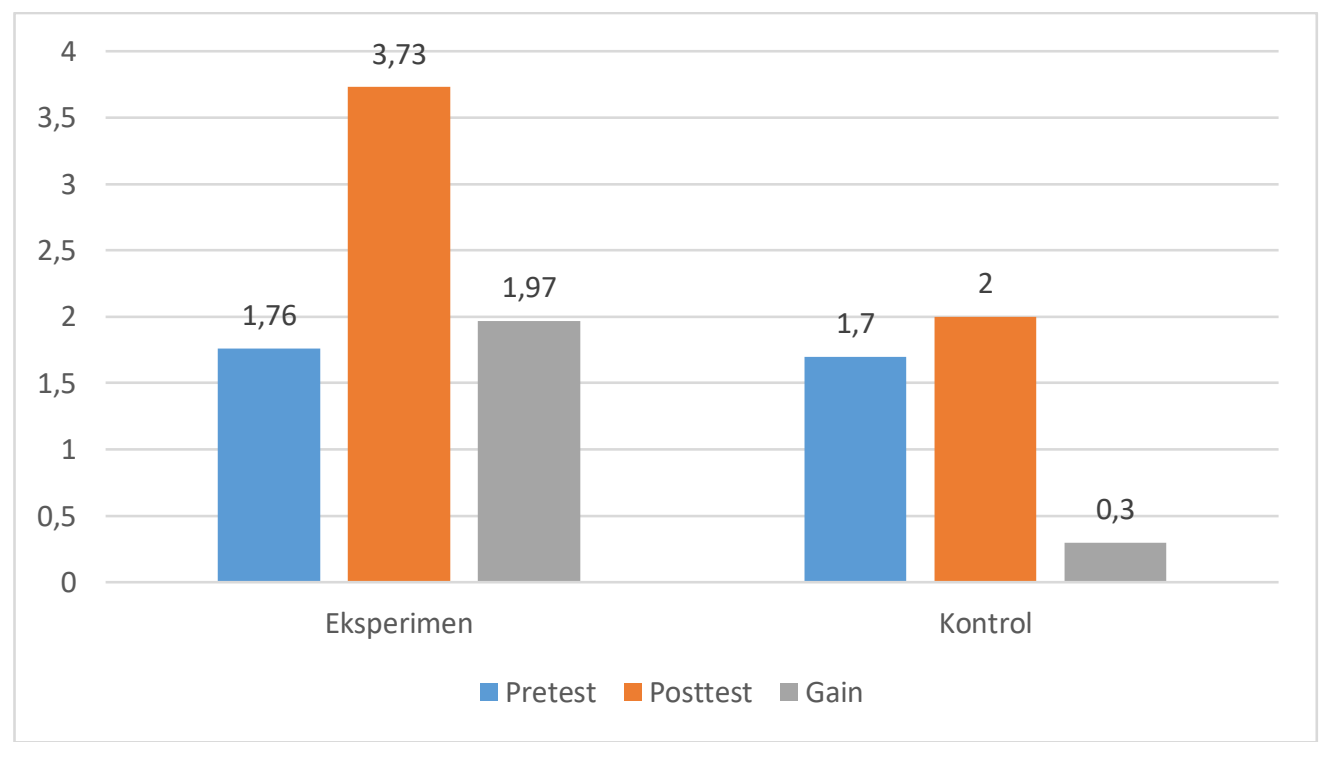

Gambar 1.2

Grafik Rata-rata Skor Awal dan Akhir Aspek Menerapkan (C3) Keseluruhan

Dari grafik di atas dapat disimpulkan bahwa skor rata-rata post-test dan gain hasil belajar aspek Menerapkan (C3) kelas eksperimen lebih tinggi dibandingkan dengan skor rata-rata post-test dan gain hasil belajar kelas kontrol.

\section{Deskripsi Hasil Penelitian Aspek Menganalisis (C4) Kelas Eksperimen dan Kelas Kontrol}

Rumusan masalah yang ketiga adalah "apakah terdapat perbedaan peningkatan hasil belajar peserta didik yang signifikan pada aspek Menganalisis 
(C4) antara yang menggunakan media pembelajaran Lectora Inspire dengan yang menggunakan media pembelajaran presentasi dalam mata pelajaran Biologi pada pokok bahasan Mekanisme Pencernaan Makanan pada Manusia di SMAN 1 Cibeber?". Adapun tujuan penelitian dari rumusan masalah yang pertama adalah untuk menguji efektivitas penggunaan media Lectora Inspire dalam peningkatan aspek Menganalisis (C4) peserta didik pada mata pelajaran Biologi.

Setelah dilakukan penelitian diperoleh data pre-test dan post-test pada kelas eskperimen dan kontrol dengan perlakuan pada aspek Menganalisis (C4). Perbedaan peningkatan hasil belajar peserta didik tersebut dapat dilihat melalui gain pada tabel berikut.

Tabel 1.4

Rata-Rata Skor Pre-Test dan Post-Test Aspek Menganalisis (C4) Kelas Eksperimen dan Kelas Kontrol

\begin{tabular}{cccc}
\hline Kelas & Pretest & Posttest & Gain \\
\hline Eksperimen & 1,82 & 4,33 & 2,51 \\
\hline Kontrol & 1,61 & 1,70 & 0,09 \\
\hline
\end{tabular}

Berdasarkan skor rata-rata pre-test dan post-test pada aspek Menganalisis (C4) untuk kelas eksperimen dan kontrol sesuai tabel 1.4 diperoleh grafik rata-rata sebagai berikut:

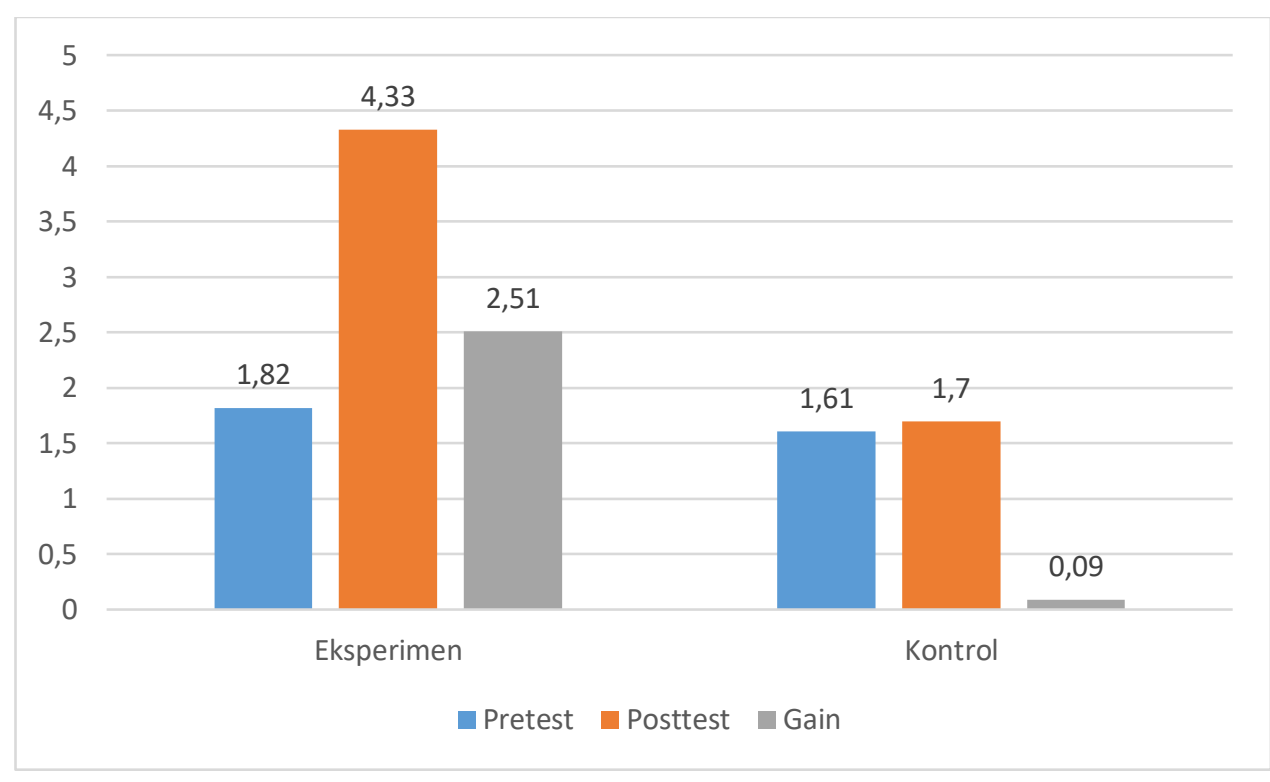

Gambar 1.3

Grafik Rata-rata Skor Awal dan Akhir Aspek Menganalisis (C4) Keseluruhan

Dari grafik di atas dapat disimpulkan bahwa skor rata-rata post-test dan gain hasil belajar aspek Menganalisis (C4) kelas eksperimen lebih tinggi dibandingkan dengan skor rata-rata post-test dan gain hasil belajar kelas kontrol.

Tujuan umum dalam penelitian ini yaitu untuk mengetahui efektivitas media pembelajaran Lectora Inspire melalui 
perbandingan signifikansi peningkatan hasil belajar belajar antara peserta didik yang menggunakan pembelajaran Lectora Inspire dengan peserta didik yang menggunakan media pembelajaran presentasi di SMAN 1 Cibeber pada mata pelajaran Biologi pokok bahasan Mekanisme Pencernaan Makanan pada Manusia.

Hasil belajar pada penelitian ini mencakup aspek Memahami (C2), Menerapkan (C3), dan Menganalisis (C4) yang tergolong dalam ranah kognitif. Hasil dari penelitian yang dilaksanakan oleh peneliti, menunjukan bahwa terjadi perbedaan peningkatan hasil belajar.

Berdasarkan pemaparan di atas, menunjukan bahwa hasil penelitian penggunaan media pembelajaran Lectora Inspire memiliki perbedaan hasil belajar yang signifikan dibandingkan dengan yang menggunakan media pembelajaran presentasi, dengan hasil belajar yang lebih tinggi pada kelas eksperimen. Temuan tersebut sejalan dengan penelitian Zulfiati (2014) aplikasi Lectora Inspire berpengaruh positif dalam meningkatkan kemampuan kognitif siswa dibandingkan pembelajaran dengan menggunakan media cetak. Hal tersebut dapat diketahui dengan memperhatikan selisih (gain) antara kelas eksperimen dan kelas kontrol yang menyatakan bahwa gain kelas eksperimen lebih tinggi dari pada gain kelas kontrol dalam keseluruhan sesi. Berdasarkan data hasil pengujian khusus menunjukan bahwa terdapat perbedaan peningkatan hasil belajar peserta didik yang signifikan pada aspek Memahami (C2) antara peserta didik yang menggunakan media pembelajaran Lectora Inspire dengan peserta didik yang menggunakan media pembelajaran presentasi dalam mata pelajaran Biologi pada pokok bahasan Mekanisme Pencernaan Makanan pada Manusia di SMAN 1 Cibeber, dilihat dari adanya peningkatan yang signifikan dari gain kelas eksperimen dibandingkan dengan gain kelas kontrol.

\section{E. KESIMPULAN}

Berdasarkan dari hasil penelitian dan analisis data pada bab sebelumnya, secara umum disimpulkan bahwa peningkatan hasil belajar peserta didik yang menggunakan media pembelajaran Lectora Inspire lebih tinggi dan signifikan dibanding dengan peserta didik yang menggunakan media pembelajaran presentasi dengan berbantuan sumber belajar berupa buku pegangan peserta didik dalam mata pelajaran Biologi pada pokok bahasan Mekanisme Pencernaan Makanan pada Manusia di SMAN 1 Cibeber, dan media pembelajaran Lectora Inspire dapat dikatakan efektif.

Terdapat perbedaan peningkatan hasil belajar peserta didik yang signifikan pada aspek memahami (C2) antara penggunaan media pembelajaran Lectora Inspire dengan yang menggunakan media presentasi dengan berbantuan sumber belajar berupa buku pegangan peserta didik dalam mata pelajaran Biologi pada pokok bahasan Mekanisme Pencernaan Makanan pada Manusia di SMAN 1 Cibeber. Hal ini dapat dilihat dari rerata yang didapat pada kelas eksperimen untuk aspek memahami (C2) yaitu 4,45 dimana lebih besar dari rerata kelas kontrol yaitu 2,42 . Hasil analisis $N$-Gain menunjukan bahwa terjadi peningkatan yang signifikan pada kelas eksperimen serta berdasarkan uji hipotesis terbukti bahwa terdapat perbedaan yang signifikan antara hasil pretest dan posttest pada kelas eksperimen.

Terdapat perbedaan peningkatan hasil belajar peserta didik yang signifikan pada aspek menerapkan (C3) antara penggunaan media pembelajaran Lectora Inspire dengan yang menggunakan media 
presentasi dengan berbantuan sumber belajar berupa buku pegangan peserta didik dalam mata pelajaran Biologi pada pokok bahasan Mekanisme Pencernaan Makanan pada Manusia di SMAN 1 Cibeber. Hal ini dapat dilihat dari rerata yang didapat pada kelas eksperimen untuk aspek menerapkan (C3) yaitu 3,73 dimana lebih besar dari rerata kelas kontrol yaitu 2,00. Hasil analisis $\mathrm{N}-$ Gain menunjukan bahwa terjadi peningkatan yang signifikan pada kelas eksperimen serta berdasarkan uji hipotesis terbukti bahwa terdapat perbedaan yang signifikan antara hasil pretest dan posttest pada kelas eksperimen.

Hasil lain juga menunjukan bahwa terdapat perbedaan peningkatan hasil belajar peserta didik yang signifikan pada aspek menganalisis (C4) antara penggunaan media pembelajaran Lectora Inspire dengan yang menggunakan media presentasi dengan berbantuan sumber belajar berupa buku pegangan peserta didik dalam mata pelajaran Biologi pada pokok bahasan Mekanisme Pencernaan Makanan pada Manusia di SMAN 1 Cibeber. Hal ini dapat dilihat dari rerata yang didapat pada kelas eksperimen untuk aspek menganalisis (C4) yaitu 4,33 dimana lebih besar dari rerata kelas kontrol yaitu 1,70. Hasil analisis $N$-Gain menunjukan bahwa terjadi peningkatan yang signifikan pada kelas eksperimen serta berdasarkan uji hipotesis terbukti bahwa terdapat perbedaan yang signifikan antara hasil pretest dan posttest pada kelas eksperimen.

\section{DAFTAR PUSTAKA}

Arsyad, Azhar. (2011). Media Pembelajaran. Jakarta: PT Raja Grafindo Persada.

Anitah, Sri. (2010). Media Pembelajaran. Surakarta: Yuma Pustaka.

Darmawan, D. (2012). Pendidikan Teknologi Informasi dan Komunikasi. Bandung : PT Remaja Rosdakarya.

Daryanto. (2011). Media Pembelajaran. Bandung: Sarana Tutorial Nurani Sejahtera.

Marfuah, Siti. (2007). Penggunaan Media Pembelajaran dalam Meningkatkan Motivasi Belajar Peserta didik pada Mata Pelajaran Pendidikan Agama Islam di Sekolah Menengah Atas Negeri 1 Pagak Malang. (Skripsi). Universitas Islam Negeri, Malang.

Mas'Ud, M. (2012). Membuat multimedia pembelajaran dengan Lectora. Yogyakarta: Pustaka Shonif.

Prawiradilaga. (2013) Mozaik Tekologi Pendidikan E Learning. Jakatra: Prenadameida group. Rusman. (2012). Model-model Pembelajaran: Mengembangkan Profesionalisme Guru. Jakarta : Raja Grafindo Persada.

Sukiman. (2012). Pengembangan Media Pembelajaran. Yogyakarta: Pedajogja.

Shalikhah, N. D. (2017). Media pembelajaran interaktif Lectora Inspire sebagai inovasi pembelajaran. Warta LPM, 20(1), 9-16.

Suharmoyo, Elyas. (2016). Mudahnya Membuat Bahan Ajar Menggunakan Lectora Inspire 16.2. Yogyakarta : IGI.

Tamimudin. (2007). Mengenal Mobile Learning. [Online] Diakses dari https://mtamim.files.wordpress.com/2008/12/mlearn tamim.pdf

Wijaya, A. H., Slamet, L., \& Said, D. L. (2018). PENGARUH APLIKASI LECTORA INSPIRE BERBASIS ICT SEBAGAI MEDIA PEMBELAJARAN INTERAKTIF PADA MATA DIKLAT SOD TERHADAP HASIL BELAJAR PESERTA DIDIK KELAS X JURUSAN 
TEKNIK KOMPUTER JARINGAN SMKN 1 TANJUANG BARU. Jurnal Vokasional Teknik Elektronika dan Informatika, 2(2).

Wijaya, S. W. (2018). Mobile Learning Sebagai Model Pembelajaran Alternatif Bagi Pemulihan Pendidikan Di Daerah Bencana Alam Gempa Bumi Yogyakarta. Jurusan Teknik Informatika, Univ. Sanata Darma.

Zulfiati, H. M. (2014). Pengaruh Pembelajaran Ips Berbasis Ict (Information And Communications Technology) Dengan Aplikasi Lectora Inspire Dalam Meningkatkan Hasil Belajar Siswa. JIPSINDO, 1(1). 